\title{
Doç. Dr. Sedit Yüksel
}

(1921-1998)

Türkoloji Dergisi'nin XV. cildi Dil ve Tarih-Coğrafya Fakültesi Türk Dili ve Edebiyatı Bölümü emekli ögretim üyelerinden Doç. Dr. Sedit Yüksel'in anısına adandı. Aynı ana bilim dalının mensubu olarak merhum hocamız hakkında bu satırları yazma görevini ben üstlendim.

Dil ve Tarih-Coğrafya Fakültesi Türk Dili ve Edebiyatı Bölümüne kaydolduğumuz 1964-1965 öğretim yılı başlarında tanıdığımız ancak rahatsızlığı nedeniyle çok kısa bir süre kendisinden ders gördüğümüz değerli hocamız hakkında yazacağım bu satırlar, ne yazık ki anılarla yüklü olamayacak; onun nezaketini, derslerdeki titizliğini yeterince anlatamayacak; Fakülte Personel Dairesindeki dosyasında bulunan bilgileri aktarmakla yetinecek.

Halime Hanım ile İsmail Bey'in oğulları Mehmet Sedit 1337 (1921) tarihinde İstanbul'da dünyaya geldi. Tokat Horuç İlkokulunu, Tokat Ortaokulunu, İstanbul Vefa Erkek Lisesini ve 1944-1945 öğretim yılında İstanbul Üniversitesi Edebiyat Fakültesi Türkoloji Bölümünü bitirdi.

01.11.1945-31.03.1947 tarihleri arasında yedek subay olarak askerlik görevini tamamladı.

Meslek hayatına Tokat Yeşilırmak Özel Lisesi edebiyat öğretmenliği ile başlayan (09.12.1947) hocamız bu görevden kendi isteğiyle ayrılmış (28.09.1948) ve Ankara V. Ortaokulu Fransızca Vekil Öğretmenliği göreviyle Ankara'da çalışmaya başlamış, bunu kısa süreli Ankara Tapu ve Kadastro Okulu Fransızca vekil öğretmenliği görevi izlemiștir. İkinci vekil öğretmenliği 01.04.1949 tarihinde sona ermiştir. Türk Eğitim Derneği Yenişehir Lisesinde 25.09.1949-01.06.1951 tarihleri arasındaki edebiyat öğretmenliği onun orta dereceli okullardaki son görevidir. 
Bu tarihlerde Dil ve Tarih-Coğrafya Fakültesi Türk Dili ve Edebiyatı Kürsüsüne asistan olmak üzere bașvuran Sedit Yüksel, yapılan sınavı kazanarak (27.04.1945) asistanlığa atanmıștır (30.04.1951). Bir yıl sonra asaleti onanan Sedit Yüksel, doktora çalışmalarına başlamış ve "Şeyh Galip, Eserlerinin Dil ve Sanat Değeri" adlı doktora tezi ile 19.06.1954 tarihinde "edebiyat doktoru" unvanını almıștır. Çok değerli ve vefakâr eși edebiyat öğretmeni Ayhan Yüksel Hanımefendi ile evlenmesi Dr. Sedit Yüksel'e 1954 yılının getirdiği ikinci mutluluktur. Bu evlilikten İnci ve Tunca adlı iki çocukları dünyaya gelmiştir.

Dr. Sedit Yüksel 27.03.1959 tarihinde doçentlik sınavına başvurmuş "Işk-nâme" adlı tezi Prof. Dr. Ali Nihad Tarlan, Prof. Kenan Akyüz, Ord. Prof. Dr. Reşit Rahmeti Arat, Prof. Dr. Ahmet Hamdi Tanpınar ve Prof. Dr. Saadet Çağatay'dan oluşan jüri tarafindan 17.10.1960 tarihinde kabul edilmiş; 03.11.1960 günü kollokyum, 14.11.1960 günü Dil ve Tarih-Coğrafya Fakültesi 231 numaralı sımıfta verdiği "Ali Şîr Nevâî'nin Edebiyatımızdaki Yeri” konulu deneme dersi aşamalarında başarılı görülerek "Üniversite Doçenti" unvan ve payesini almıștır. Doç. Dr. Sedit Yüksel 30.12.1960 tarihinde "eylemli doçent"liğe atanmış ve aynı tarihte Bölümümüzdeki görevine bașlamıştır.

Doç. Dr. Sedit Yüksel, 1963 yılı kış aylarında İngiltere'de araștırma yapmak üzere 3 aylık izin istemiș, bu isteği Fakülte ve Üniversite tarafından uygun görülmüş, izin süresi bir ay uzatılmış ve 1964 nisan ayında Fakültedeki görevine dönmüsstür.

Değerli Hocamız 07.12.1964 tarihinde yüksek tansiyona bağlı beyin kanaması tanısıyla Ankara Hastanesine yatırılmıș; sonradan tanı ve tedavinin yanlış olduğu anlaşılmış, Hacettepe ve Ankara Üniversitesi hastanelerinde yapılan tedavilerle tam olarak sağlı̆ı̆ı kavuşamamış; Ankara Üniversitesi Tıp Fakültesi raporuyla Zürih Üniversitesi Hastanesinde 24.06.1965-21.07.1965 tarihleri arasında tedavi görmüş̧ür. 22.07.1965'te görevine dönen Hocamız, rahatsızlığı uzun süreli çalıșmaya engel olduğundan, Fakültece Ankara kitaplıklarında araştırma 
yapmak üzere görevlendirilmiş ve bu görevlendirmeler birbiri ardınca yinelenmiştir. 14.10.1975 tarihinde emekli olmak üzere başvuran hocamızın bu dileği Rektörlükçe kabul edilmiştir.

Doç. Dr. Sedit Yüksel hocamızın emeklilik işlemleri tamamlandıktan sonra Dil ve Tarih-Coğrafya Fakültesi Dekanlığına "Toplanacak ilk Profesörler Kurulunda okunması ricasıyla" 11.12.1975 tarihinde gönderdiği içten ve duygu yüklü yazısı, o kurulda okundu mu bilemiyorum; okunmuşsa dinleyenlerin hatırlamaları, o günlere yetişemeyenlerin de Doç. Dr. Sedit Yüksel nezaketini kendi satırlarında görmeleri için bu yazıyı aktarmak istiyorum:

\section{"Yüce Kurula}

Aralık 1975 'te emekliye ayrılmış bulunuyorum. Siz değerli arkadaşlarıma ayrı ayrı veda etmeği çok isterdim. İçinde bulunduğum koşullar bu ödevi yerine getirmeme engel olmaktadır. Beni sizden ayrı kalmaya zorlayan güç ve üzüntülü günlerim boyunca göstermiş olduğunuz canlı ve sıcak ilgilerinize teșekkürü, yerine getirilmesi gerekli bir vicdan borcu sayıyorum. Hepinize 'Allah'a ısmarladık' diyor, hep böyle bir arada, sağlıkhı nice çalıșma yıllanı diliyorum. Saygilarmia.

\section{Eski Türk Edebiyatı Kürsüsü Emekli Öğretim Üyesi Doç. Dr. Sedit Yüksel"}

6.11.1998 günü kaybettiğimiz değerli hocamız Doç. Dr. Sedit Yüksel'i rahmet dileklerimiz ve saygı ile anıyoruz.

Doç. Dr. Sedit Yüksel'in Yayınları:

1. "Balzac (H.de)", Türk Ansiklopedisi, C.V.

2. "Barry (Mme.du)", Türk Ansiklopedisi, C.V.

3. "Şeyh Galip, Hayatı ve Sanatı" Türk Dili, S.22, (1953).

4. "Şeyh Galip'in Bilinmeyen Kasideleri”, Devrim Gençliği, S.19, (1954). 
5. "Biyografya" (ortak), Türk Ansiklopedisi, C.VII.

6. "Şeyh Galip Hakkında Notlar", Türk Dili, S.53, (1956).

7. Fuzulî Divanı (ortak), Türkiye İş Bankası Yayını, Ankara, 1958.

8. Şeyh Galip, Eserlerinin Dil ve Sanat Değeri, Ankara Üniversitesi Dil ve Tarih-Coğrafya Fakültesi yayını, Ankara, 1963; 2. bs. Türkiye İş Bankası yayını, Ankara, 1980.

9. "Şeyh Galip", Türk Ansiklopedisi, C.XXX.

10. Mehmed, Işs-nâme, Ankara Üniversitesi, Dil ve TarihCoğrafya Fakültesi yayını, Ankara, 1965.

11. "Işk-nâme Üzerine Açıklamalar", Türk Dili, S.220, (1970).

12. "Gün Ișığına Kavuşturulan İki Yeni Eser”, Türk Dili, S.237, (1971).

13. "Sohbetü’l-Esmâr Fuzulî’nin Değildir", Türkoloji Dergisi, C.IV, (1972).

14. "Kitabı Onurlandıran Koca Ragıp Paşa", Milliyet Gazetesi, 28 Nisan 1973.

15. “Koca Ragıp Paşa'nın Bilinmeyen Gazelleri”, Türkoloji Dergisi, C.VI, (1974).

16. “Koca Ragıp Paşa'nın Ramazaniyesi”, Türkoloji Dergisi, C.VII, (1977).

17. "Eski Edebiyatımızda Ramazan", Türkoloji Dergisi, C.VII, (1977).

18. "Koca Ragıp Paşa'nın Sanatında ve Yaşantısında Haşmet ve Fitnat'ın Yeri”, Türkoloji Dergisi, C.VII, (1977).

İsmail Ünver 